\title{
African musics in context: institutions, culture, identity/Ethnomusicology in East Africa: perspectives from Uganda and beyond
}

\section{Andrew J. Eisenberg}

To cite this article: Andrew J. Eisenberg (2017): African musics in context: institutions, culture, identity/Ethnomusicology in East Africa: perspectives from Uganda and beyond, Ethnomusicology Forum

To link to this article: http://dx.doi.org/10.1080/17411912.2017.1323658

曲 Published online: 15 May 2017.

Submit your article to this journal $\pi$

Q View related articles $\asymp$

View Crossmark data $\complement$ 
BOOK REVIEW

African musics in context: institutions, culture, identity, edited by Thomas

Solomon, Kampala, Uganda, Fountain Publishers, 2015, xxvi + 365 pp., $£ 28.00$

(paperback), ISBN 978-9-970-25245-9

\section{Ethnomusicology in East Africa: perspectives from Uganda and beyond, edited by Sylvia Nannyonga-Tamusuza and Thomas Solomon, Kampala, Uganda, Fountain Publishers, 2012, xvi + 255 pp., $£ 34.00$ (paperback), ISBN 978-9-970-25135-3}

These volumes bring a group of Ugandan ethnomusicologists at various stages of their careers into dialogue with Bergen-based American ethnomusicologist Thomas Solomon and a handful of other Africa-based and UK-based scholars. They grow out of symposia organised as part of the Makerere-Bergen Collaboration in Ethnomusicology, a Norwegian-funded partnership between the Department of Performing Arts and Film at Makerere University in Kampala, Uganda and the Grieg Academy-Department of Music at the University of Bergen, Norway. Thomas Solomon, who serves as editor for both volumes, is not an Africanist (and does not claim to be), but the Makerere-Bergen Collaboration brought him into intensive contact with Ugandan researchers as a teacher and mentor. He is joined in his editorial role in the first of the volumes, Ethnomusicology in East Africa by accomplished Ugandan ethnomusicologist Sylvia Nannyonga-Tamusuza.

Billed as an attempt to establish ethnomusicology as a professional discipline in Uganda, the volumes feature a number of Ugandan contributors who were just beginning their careers as professional researchers at the time of their writing, having recently earned master's degrees through the Collaboration under the tutelage of Solomon. As a result, most chapters do not offer highly developed or innovative theoretical or methodological insights, and many are laden with the stylistic peculiarities one would expect from scholars still learning to 'manage the conventions of international (but ultimately Euro-American-derived and dominated) scholarly practice' (Ethnomusicology in East Africa, 238). But the volumes are consistently readable and present a great deal of solid, original research on a variety of topics.

Seventeen of the 27 chapters across the two volumes are ethnographic case studies based on original research in Uganda or neighbouring Tanzania. While generally brief, they are all rich in empirical detail and clearly grounded in excellent fieldwork. The major themes are religious and ritual practice, and identity politics. Within these themes a nice balance is struck with respect to empirical focus, with chapters on Islam as well as Christianity, and the popular as well as the traditional. A few chapters fall outside the major thematic areas. Among these is one of the strongest chapters, Dominic D. B. Makwa's sensitive ethnography of musical practices of place making among natural disaster survivors (African Musics in Context, Chapter 11), which also happens to be one of the chapters that most reveals the influence of Thomas Solomon, whose interest in issues of emplacement is longstanding.

The most glaring shortcoming of the ethnographic case studies is their nearly uniform use of the classical anthropological voice. The problem here lies not only in the resulting lack of stylistic variety in the chapters, but also in what is potentially lost or obscured by virtue of all these authors adopting this voice. After all, as many (Euro-American) anthropologists and ethnomusicologists have argued since the late 1980s, this style of ethnographic writing favours the sorts of generalisations that implicitly characterise social groups as bounded and coherent, leaving little room for capturing the messy relationality of social identification. 
The only marked deviation from the classical anthropological voice comes in Sylvia Nannyonga-Tamusuza's chapter in Ethnomusicology in East Africa (Chapter 14), which employs first-person narration to explore ethnographically the production and circulation of ideas about African music in the Scandinavian context. This chapter also happens to be the only one across both volumes that can adequately be described as polemical. It includes a strong critique of the notion of 'African music', responding to criticism from some African scholars of earlier remarks she had made on the subject. Nannyonga-Tamusuza contends that 'African music does not exist' except as a 'brand name', and that '[this] categorisation perpetuates a romanticised, abstract and idealised Africa' (204). She rejects the ideas of an essentialised 'African' music proffered by twentieth-century African thinkers like Léopold Sédar Senghor and the eminent African musicologist J. H. Kwabena Nketia as 'outmoded' at best and 'orientalist' (that is to say, racist) at worst. It is a strong, even dogmatic position, if defensible on empirical grounds. But that is perhaps the point, because Nannyonga-Tamusuza seems more interested in closing off this discussion than taking it in a new direction. I, for one, hope she does not get her wish, even though I am largely sympathetic to her position. The question of whether or not there is such a thing as 'African music' is ultimately bound up with a broader set of epistemological and ethical questions of representation, and so deserves a more nuanced approach.

Another thread that runs throughout all of the ethnographic case studies across both volumes is a lack of close attention to formal aspects of musical sound, poetic texts or movement. This is quite a break from earlier ethnomusicological scholarship on Uganda by European scholars like Klaus Wachsmann, Peter Cooke and Gerhard Kubik, which largely deals with matters such as tuning systems and melodic structures. It is unfortunate that the editors' introductions do not reflect on this paradigmatic disjuncture, especially given that the first volume begins with a chapter by Peter Cooke on Klaus Wachsmann (as I will discuss presently).

Each volume begins with a collection of chapters that do not fit the ethnographic case study mould. Appropriately, the first volume, Ethnomusicology in East Africa, begins with a section on the legacy of Klaus Wachsmann, the pioneering Africanist ethnomusicologist who spent the Second World War and the decade that followed employed as a researcher and museum curator in Uganda. Wachsmann's voluminous writings and field recordings, which placed Uganda at the centre of ethnomusicological knowledge production during the formative decades of the discipline, may provide a rich corpus of primary and secondary sources for contemporary Ugandan scholars-especially now that Ugandans have easier access to Wachsmann's more than 1500 audio recordings through the Makerere University Klaus Wachsmann Archive established in 2009. Unfortunately, none of the chapters in this section offers a thorough overview of Wachsmann's oeuvre. Indeed, only two of the four chapters are really about Wachsmann at all (and one of these, an idiosyncratic contribution from Wachsmann's son Philip Wachsmann, only nominally so). Cooke's personal reflections on Wachsmann's life are useful, but merely scratch the surface of Wachsmann's legacy (Ethnomusicology in East Africa, Chapter 1).

A more intensive engagement with Wachsmann's legacy comes in the second volume, in a lengthy (for these volumes) chapter by Nannyonga-Tamusuza (African Musics in Context, Chapter 3). In this chapter, Nannyonga-Tamusuza takes a deep dive into the written documentation of Wachsmann's field recordings, offering a great deal of useful context for the materials and advocating for better custodianship of them going forward. This chapter is one of the highlights of the two volumes, and should be required reading for all Ugandan and Uganda-focused ethnomusicologists. It stands in a productive dialogue with two other chapters on the roles of archives and archival materials in ethnomusicological research situated 
across the two volumes-one by Janet Topp Fargion of the British Library Sound Archive (Ethnomusicology in East Africa, Chapter 4) and the other by Diane Thram of the International Library of African Music in South Africa (African Musics in Context, Chapter 4).

African Musics in Context begins with contributions from two Ugandan professionals working outside the academy, one in the public sector and one in the music industry. The pieces are brief, and each a little quirky in its own way. But they effectively reveal the sorts of questions that Uganda's credentialed ethnomusicologists may be called upon to confront as the field matures. These include the broad theoretical questions that to some extent animate all of the research featured in the two volumes: what is music, in Uganda and elsewhere, and how does it relate to other aspects of life; what does music have to do with ethnic and religious identification in Uganda; is there a 'Ugandan' music? But they also include normative questions about the proper role of music in projects of nation-building and economic development (i.e. questions of music policy). There is no hint in these volumes that such questions will find their way to the centre of Ugandan ethnomusicology. On the contrary, the most thoroughgoing approach to the issue of Ugandan national identity in the volumes takes the form of a critical ethnographic analysis of touristic performance (African Musics in Context, Chapter 8).

Each volume ends with an ambitious, programmatic chapter by Thomas Solomon. In Ethnomusicology in East Africa Solomon's topic is postcoloniality and postcolonial approaches to ethnomusicology (Chapter 15); in African Musics in Context it is diaspora and hybridity (Chapter 12). Solomon's chapter in Ethnomusicology in East Africa, 'Where is the Postcolonial in Ethnomusicology?', aims at articulating the underlying project of the two volumes. Clearly oriented towards both Euro-American and Ugandan audiences, it suggests ways in which ethnomusicology may be well positioned to contribute to postcolonial discussions of difference and representation, and how the discipline might itself be 'decolonised'. With respect to the latter issue, Solomon stresses the need for scholars in the Global North to work collaboratively with scholars in the Global South to support the expansion of the field outside the traditional centres of knowledge production. This, of course, is exactly what Solomon is doing in these volumes. Indeed, Solomon explicitly frames the volumes as a project of 'decolonising ethnomusicological practice' (Ethnomusicology in East Africa, 235) by fostering the growth of 'professionalised ethnomusicology in Uganda' (African Musics in Context, xxvi).

These two volumes will certainly be of value to music scholars focused on East Africa (and Uganda in particular). They may also prove interesting and inspiring for scholars who are interested in ways of decolonising the discipline. If the recent themed issue of SEM Student News on 'Decolonizing Ethnomusicology' (Volume 12, Number 2, 2016) is any indication, this is a constituency that includes many emerging voices in the field.

Andrew J. Eisenberg

New York University Abu Dhabi

@andrew.eisenberg@nyu.edu

(C) 2017 Andrew J. Eisenberg

https://doi.org/10.1080/17411912.2017.1323658 